Document downloaded from:

http://hdl.handle.net/10251/104906

This paper must be cited as:

Marques, P. (2017). From toys to automobiles: foreign investment, firm heterogeneity and intermediaries in a Portuguese industry. European Planning Studies. 25(8):1375-1393. doi:10.1080/09654313.2017.1303822

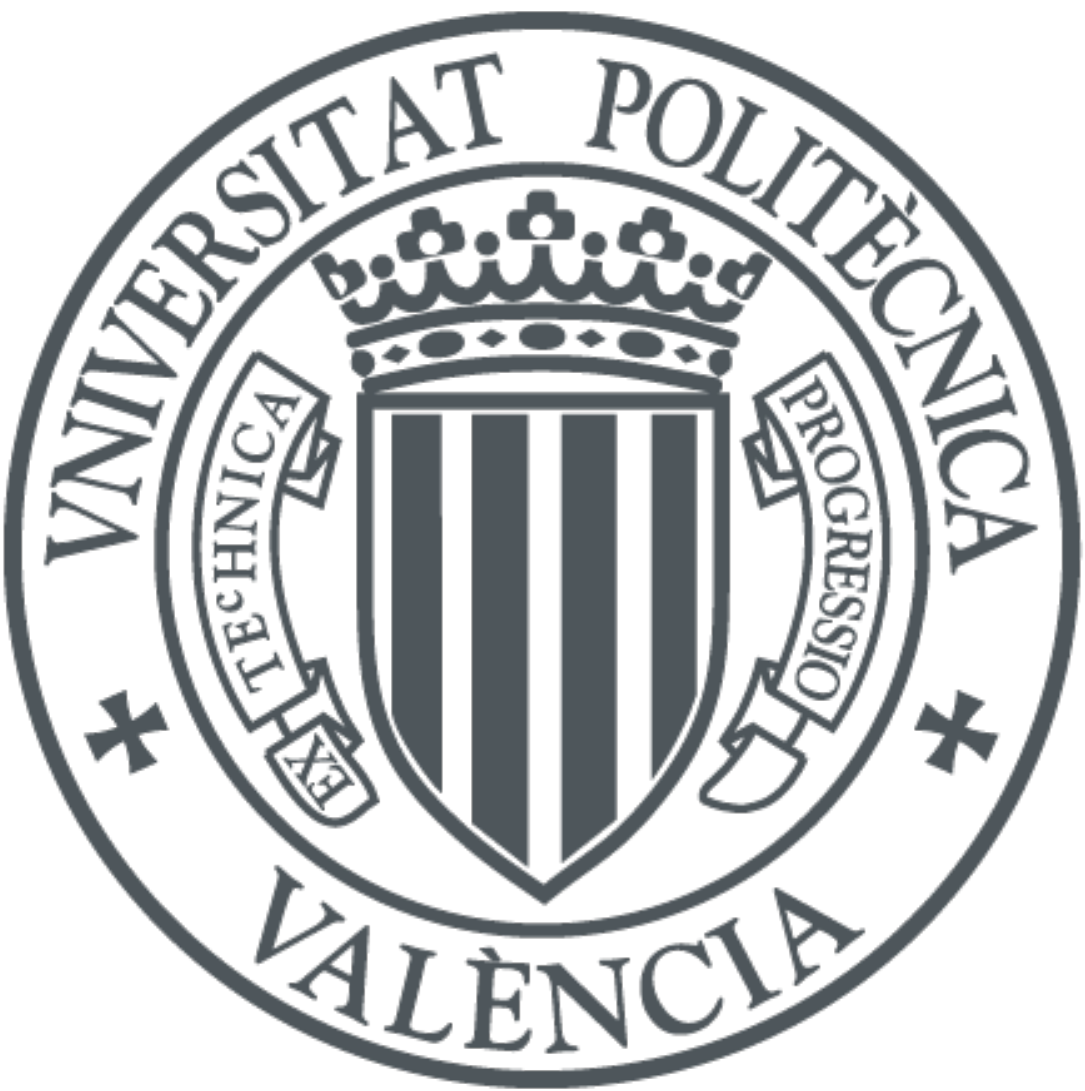

The final publication is available at

https://doi.org/10.1080/09654313.2017.1303822

Copyright Taylor \& Francis

Additional Information 


\title{
From toys to automobiles: foreign investment, firm heterogeneity and intermediaries in a Portuguese industry
}

\author{
Pedro Marques \\ INGENIO (CSIC-UPV), Universitat Politècnica de València, Valencia, Spain
}

Version accepted for publication. Please cite as:

Marques, P. (2017). 'From toys to automobiles: foreign investment, firm heterogeneity and intermediaries in a Portuguese industry’. European Planning Studies, advanced online access: https://doi.org/10.1080/09654313.2017.1303822

50 free eprints available at this link:

http://www.tandfonline.com/eprint/zgjh5QB7HnyaX48vq2yI/full

\section{Funding}

Research for this article was supported by the fellowship SFRH/BD/27431/2006 from the Fundação para a Ciência e a Tecnologia (Portugal). This fellowship programme is funded by the Programa Operacional Potencial Humano and the European Social Fund. 


\begin{abstract}
In the literature on territorial innovation systems there is a constant tension between the effect of endogenous and exogenous factors and their relative importance. In order to address this tension several approaches have sought to conceptualize the relational and multi-scalar dimension of innovation and to explain how external knowledge and economic flows in conjunction with regional contexts combine to produce regional growth, stagnation or decline. This paper will contribute to this debate, while also highlighting that even at the local level there is substantial heterogeneity between firms. It will also shed light on the role of intermediary organizations that can help address information and power asymmetries between multinational corporations and less competitive local firms. Empirically it will draw on the case study of the Portuguese moulds industry, which has successfully adapted to shifts in the global economy by drawing on local resources while also remaining integrated into global value chains.
\end{abstract}

\title{
1. Introduction
}

Drawing on a variety of concepts, which Moulaert and Sekia (2003) termed territorial innovation models (TIM), it has been demonstrated that knowledge externalities and the systemic interaction between agents (including firms, universities, business or workers associations, and end users) are essential to sustain learning and innovation, and that these dynamics tend to be concentrated in specific places (Pike et al 2006). It has also been argued that once a particular set of conditions materialise in a location they tend to have mutually reinforcing effects and generate a set of formal and informal institutions which constrain future development (Cooke 2012, Jakobsen et al 2005). The combination of these two processes of cumulative causation and path 
dependency, make a significant contribution to explain different rates of regional innovation and economic growth (Myrdal 1957, Jakobsen et al 2005).

Earlier versions of TIM were however criticised for over-emphasising the importance of endogenous (to the region) characteristics, while ignoring the importance of exogenous elements (Marques 2011). Among the latter, we find the importance of knowledge and economic flows from foreign sources. These flows can take the form of foreign direct investment (FDI), which have a significant effect on regional economic structures, particularly in regions that do not host multinational headquarters (Jakobsen et al 2005, MacKinnon 2012). They can also happen by integrating local firms into global value chains (GVC) as suppliers of multinational corporations (MNC) (Blažek 2015). The scale and scope of the impact of these economic flows on the innovative capabilities of local firms results from an interaction between the strategic intent of the multinational corporation (MNC) and the characteristics of the region (Jakobsen et al 2005).

Importantly, the impact of foreign investments varies not only across regions, but also within regions, due to the internal heterogeneity of their productive structures. This heterogeneity refers to differences between co-located firms in terms of their absorptive capacities, and their capacity to establish local, national or international links, in their search for knowledge and access to new markets (Lorentzen 2007, Rabellotti and Schmitz 1999). Additionally, because these links are established in contexts of information and power asymmetries (Christopherson and Clark 2007, Tokatli 2007), they are ripe for the emergence of intermediary organisations (Howells 2006a, 2006b), which are responsible for mediating and managing the interaction between SMEs and MNCs, with both positive and negative implications. 
Empirically this paper will draw on the case study of the Portuguese moulds industry for plastic injection, which is overwhelmingly concentrated in two Portuguese regions. This industry has been extremely successful in the Portuguese context, in terms of its capacity to operate at the forefront of technological development while growing in size. Its firms have also been successful in finding new target markets, starting with the toy industry in the 1960s, the electronics (and others) industry in the 1980s, and the automobile industry, which currently absorbs nearly $80 \%$ of Portuguese moulds. This case study will be used to discuss the following research questions: How has the Portuguese moulds industry been affected by foreign investments and demand? At what scales are local firms operating to access technology and new markets? What role do intermediaries play in creating bridges between local firms and MNCs?

This paper is structured as follows: section two will introduce the theoretical approach, followed by a description of methodology used in the case study in section three. Section four will provide a brief contextualisation of the Portuguese moulds industry. In section five the results from this case study will be discussed, and finally in section six some concluding remarks will be drawn.

\section{Regional innovation and foreign investment}

Research on territorial innovation models (TIM) has demonstrated the importance of local socio-economic dynamics to sustain growth and development (Cooke et al 2004, Moulaert and Sekia 2003). These dynamics include systemic and frequent interactions among knowledge producing organisations (such as research institutes), knowledge exploiting organisations (primarily firms) and other relevant supporting entities (such as chambers of commerce or regional authorities) (Marques 2011, Cooke et al 2004). 
Dense or 'thick' organisational environments, such as those found in large agglomerations, are thought to be particularly appropriate for the emergence of such dynamics (Rodríguez-Pose and Fitjar 2013). This is because they have the resources to generate both specialised knowledge externalities (so-called Marshall-ArrowRomer externalities), which are beneficial for the development of intermediate and mature industries, and diversity (or Jacobs type) externalities, which tend to perform a critical role when industries are at a nascent stage (Neffke et al 2011).

This emphasis on the endogenous features of TIM should however be complemented by an understanding of how external factors shape the development of regional characteristics. This is at the core of relational approaches to economic development, which seek to shift the locus of research away from existing structures towards the "networks of actors, the flow of knowledge and assets within these networks, and the interconnectivity of various networks” (Fløysand and Jakobsen 2011 pp. 329). This was in fact, according to Fløysand and Jakobsen (2011), a core concern of early research on innovation system, particularly the work of Lundvall (2010), which saw innovation as a dynamic and iterative process, sustained by interactive learning and networking. Such concerns are particularly important in peripheral or less developed regions, which often lack the endogenous resources to generate knowledge externalities and are, as a consequence, more dependent on external flows (Fløysand and Jakobsen 2011, Rodríguez-Pose and Fitjar 2013). These flows include new knowledge and ideas, which prevent a narrowing of the knowledge base and lock-in, but also economic flows, which create demand for the goods and services produced within the region. This paper will start by discussing the importance of economic flows, which have received relatively less attention in the TIM literature. 
One way in which regional economies are affected by external flows is through the impact of foreign investments or demand. Foreign direct investment (FDI) is probably the most studied process in this area, due to its magnitude and the effect it has had not only on the peripheral regions in the developed world (Phelps et al 2003), but also on the rise of the East Asian economies (Amsden 2001). According to Jakobsen et al (2005) there are two main outcomes from the interaction between FDI and local conditions: FDI as development, which would be the case for countries such as Taiwan or Malaysia (Amsden 2001, Lee and Tan 2006), where it has led to vertical linkages with local firms, knowledge spillovers or technological transfer. The second outcome is FDI as dependency, a phenomenon also known as branch-plant syndrome (Kleibert 2016), which occurs when vertical linkages are limited, power relations are highly asymmetrical and the main impact on the local economy is through the employment generated by the subsidiary. As pointed out by MacKinnon (2012), many regions go through multiple rounds of investment, divestment and reinvestment, which means that FDI may have different impacts in the same region in different time-periods or depending on the firm (see also Dawley 2007). Nonetheless this distinction between two main outcomes is useful as a guide to further analysis.

The impact of foreign investment is usually determined by a combination of the strategy of the multinational corporation (MNC) doing the investment and the local conditions. Starting with the influence of the MNC strategy on the local economy, the work of Gereffi et al (2005) on global value chains (GCV) provides a useful conceptual tool to understand how it can affect local suppliers differently. The authors identified five GCV governance modes: hierarchy, captive, relational, modular, and market. The first type, hierarchy, refers to subsidiaries and governance is characterised by vertical integration. In this mode technology is accessed directly from 
headquarters, though it might vary depending on the degree of autonomy enjoyed by the affiliates. This influences their capacity to diffuse this technology locally (Sasidharan and Kathuria 2011) and is more likely to lead to branch-plant economies. In captive value chains small suppliers face significant switching costs. Such networks are frequently characterised by a high degree of monitoring and control by lead firms. MNCs will specify which technology and capabilities are necessary to be a supplier, which means a certain degree of technological transfer, but there will be few opportunities for the development of innovation capabilities.

Relational value chains are characterised by complex interactions between buyers and sellers, which often creates mutual dependence and high levels of asset specificity. This may be managed through reputation, or family and ethnic ties. Many authors have highlighted the role of spatial proximity in supporting relational value chain linkages, but trust and reputation might work as a substitute in spatially dispersed networks (Menkhoff, 1992). In modular value chains, suppliers typically make products to a customer's specifications, which may be more or less detailed. However, when providing ‘turn-key services’ suppliers take full responsibility for competencies surrounding process technology, use generic machinery that limits transaction-specific investments, and make capital outlays for components and materials on behalf of customers.

These two types of governance, relational and modular, imply a higher degree of autonomy, which grants the suppliers more freedom to pursue their own strategies and innovation strategies. It usually also involves suppliers providing a variety of design and engineering services, that support the production of the core good or service that they offer (Blažek 2015). In terms of technological transfer, it is more likely that it 
will take the form of interactive learning as defined by Lundvall (2010), where both parties engage in a process of mutual learning and technological upgrading, even if power asymmetries between firms remain. Finally, there are market based value chains. Market linkages do not have to be completely transitory and they can persist over time, with repeat transactions. The essential point is that the costs of switching to new partners are low for both parties. In this type of relationship, there will be limited or no technological transfer, with all responsibilities for knowledge acquisition falling on the supplier (Pietrobelli and Rabellotti 2011).

Importantly, the governance mode chosen by the MNC is determined not only by the characteristics of the technology or the firm's business strategy, but also by the capabilities of the supply base (Gereffi et al 2005). In this paper these capabilities are described as local conditions, which exist at the firm and regional levels. At the firm level, the previous absorptive capacity of firms has been defined as one of the core variables determining the impact of foreign investments on local economies (Li 2011). This is because firms with higher absorptive capacity can more easily adopt foreign technology and increase their competitiveness, thereby facilitating the establishment of relational or modular governance modes. At the regional level, Jakobsen et al (2005) refer to the existence of an entrepreneurial culture as a core feature of those regions that can take greater advantage of FDI investments. Also at the regional level, the literature on TIM would indicate that the presence of both knowledge producing and knowledge generating organisations, and good network links among local actors (including other supporting organisations), would lead to an environment where FDI is more likely to generate development. 
The interaction between endogenous and exogenous characteristics is shaped by a relational process, which is constantly evolving and therefore generating different outcomes in each geo-historical context (MacKinnon 2012). However, as relational approaches would emphasise, it is incorrect to treat the region as a homogenous aggregate. Within any given context, the outcome of this interaction is influenced also by the capacity of individual firms to establish relationships at different spatial scales that allow them to source knowledge and seek new markets (Lorentzen 2007).

\subsection{Intra-regional heterogeneity and intermediaries}

Regional economic structures tend to be heterogeneous (Gebreeyesus and Mohnen 2013), with differences in absorptive capacity and overall economic performance meaning that local firms will be affected differently by foreign investment. This point was illustrated for example by Murphy (2012) when discussing the wood sector in Bolivia, who showed that firms located close to each other and in the same sector use different types of networks to access global production networks (GPNs), depending on their internal characteristics and their target markets. These networks have different internal dynamics, which means that belonging to one of these networks influences the opportunities that firms encounter for value enhancement and capture.

A similar point had been made by other authors when studying the internal dynamics of localised industries. Staber, for instance $(2007,2009)$ has demonstrated empirically how, in what are at first sight homogeneous clusters, there is a persistence of what the author calls 'dysfunctional beliefs'. Staber was referring to the persistence of mistrust and rivalry, which causes agents to engage with each other in a biased and uneven manner. This leads to the emergence of closed networks and prevents the circulation of knowledge in the way described in ideal-type models of regional innovation 
(Marques 2011). In the context of shoemaking industrial districts in Italy, Brazil and Mexico, Rabellotti and Schmitz (1999) showed how there are important variations in terms of size and performance between firms, with implications for their absorptive capacity, innovative potential and capacity to grow.

The persistence of closed networks and substantial differences in firm capabilities influences the capacity of organisations to engage with partners at the regional, national or international scales (Lorentzen 2007, Vale and Caldeira 2007). This is important because firms located away from major centres of knowledge production often have to extend their networks geographically in order to access new ideas, through what Rodríguez-Pose and Fitjar (2013) called the pipeline option. Once this knowledge is accessed and absorbed, it is then spread locally through processes of anchoring which depend on local connections and opportunities for dissemination among partners and competitors (Vale and Carvalho 2012). If firms lack the capacity to engage in multi-scalar knowledge networks, or if local mechanisms for anchoring are affected by dysfunctional beliefs, this can have a negative impact on the development of the industry as a whole and the capacity of its firms to capture value within a GVC.

This emphasis on heterogeneity also helps to draw attention to a phenomenon that has been relatively unexplored in this literature, which is the role of intermediary firms or agents in linking local firms with MNCs (Howells 2006a, 2006b). One of the main functions of intermediary organisations is to diminish transaction costs by building relationships with both MNCs and local firms (Iturrioz et al. 2015, Vedel and Ellegaard 2013). Particularly in what concerns issues such as reliability, trustworthiness or quality control, a MNC might struggle to monitor effectively a 
large number of suppliers, especially if the relationship is based on arms-length relationships (Vedel and Ellegaard 2013). The intermediary organisation deals with this issue by allowing the MNC to engage only with one entity, which in turns performs the role of monitoring at the local level, where it is likely to have an extensive network of contacts and good knowledge of firm capabilities (Iturrioz et al. 2015, Vedel and Ellegaard 2013).

Nonetheless, though research on this topic tends to emphasise how intermediaries can reduce opportunistic behaviour among suppliers, it should also be noted that they can use their position as gatekeepers to be opportunistic in their relationship with suppliers (Tokatli 2007). Using their position as gatekeepers, intermediaries can put pressure on suppliers to cut costs and damage long-term innovation, as will be demonstrated by the empirical data collected for this paper. This situation is more likely in contexts of heightened competition and market volatility, and it will have a stronger effect on firms with less capacity to either link directly with MNCs or to offer a distinctive and unique product.

\section{Methodology}

The theoretical framework presented in the previous paragraphs will be discussed through a case study of the Portuguese moulds industry. This case study involved 30 interviews with firm owners and other stakeholders between 2007 and 2008 (see table 1 for a detailed list of interviewees). Additionally, these data were complemented with an analysis of several secondary sources (Beira 2007, Beira and Gomes 2007, Beira et al. 2003, Beira and Menezes 2003, Gomes 2005, Mota and Castro 2004a, 2004b, Winther 2003) and with recent information on the evolution of this industry in terms of its size, annual turnover and exports (CEFAMOL 2015). Though the interviews 
done for this case study were conducted before the financial crisis, part of the interview script was about the trends in the evolution of this industry, which have been unfolding for decades. The results were therefore considered to remain pertinent, because the aim is not to examine current strategies, but rather the evolutionary interaction between local firms and foreign demand.

(Table 1 about here)

The results obtained from these interviews were also triangulated with three datasets: one using the Quadros de Pessoal, a database managed by the Portuguese Ministry for Economics; a second dataset compiled by the author of this paper about the associates of CEFAMOL (the association representing mould producers in Portugal), using data available on its website; and a third one compiled by CEFAMOL using several sources of information, including phone lists, phone contacts and the personal knowledge of these involved in collecting the data. Additionally this information was complemented with document analysis, particularly articles written for the magazine O Molde, published by CEFAMOL.

\section{The moulds industry}

Moulds are intermediate goods, used in the production of final parts. In this paper the focus is on moulds for plastic injection. In the Portuguese and international contexts this subset of the industry is the most technologically advanced (Beira and Menezes, 2006). The production of moulds for plastic injection began in Portugal during the 1940s, first in the region of Marinha Grande and later in Oliveira de Azemeis (Gomes, 
2005). However its origins can be traced back to the presence of the glass industry in both these towns since the $18^{\text {th }}$ century (Gomes, 2005). From the latter emerged a spin-off firm producing moulds for glass and eventually, through a chance encounter between a Portuguese entrepreneur and an intermediary with connections to the US toy industry (Beira and Gomes, 2007), a producer of moulds for the plastic industry. Since 1986, when Portugal joined the European Union, annual turnover increased exponentially, mostly to other member-states, and so did the number of firms.

Internationally the moulds industry has changed significantly in recent decades. Two changes in particular deserve to be highlighted: first a general 'shift eastwards', with an increasing amount of production in East Asia but also in Central and Eastern European countries (Fallböhmer et al. 1996). According to Beira and Menezes (2006) the trend towards low cost countries means that in the short-term $70 \%$ of all moulds will be purchased in the latter. Nevertheless the EU remains a net exporter of these goods (Beira and Menezes, 2006), due to its dominance in the production of highprecision, high-complexity moulds. Second was the growth of the automobile industry as the main client for moulds produced in developed countries (USICT, 2002). In Portugal the dominance of the automobile industry reached its peak in 2007, when it absorbed 78\% of total production, up from 14\% in 1991 (CEFAMOL, 2015).

Overall the Portuguese moulds industry for plastic injection has performed relatively well in recent years (CEFAMOL 2015). Total production doubled from €360M in 2001 to $€ 660 \mathrm{M}$ in 2014 (figure 2). Despite the economic crisis, it has registered its highest ever outputs between 2012 and 2014, which means that Portugal is currently the world's $8^{\text {th }}$ largest producer of moulds and the $4^{\text {th }}$ in Europe (measured in value). This industry has from its inception been oriented towards exports, which have accounted for around 90\% of total production since the beginning (Mota and Castro 
2004a). Between 2005 and 2010 the total number of firms identified as moulds producers in national databases decreased from 543 to 448, which means that despite an increase in total turnover, the total number of firms has declined. This is not surprising since the tendency has been for a concentration of economic activity in a smaller number of very competitive firms, as will be discussed in the following section.

(Figure 1 about here)

(Figure 2 about here)

\section{Evolution of the moulds industry}

This empirical discussion will start by analysing how foreign demand has affected the Portuguese moulds industry and its regional context. It has mostly happened by the incorporation of Portuguese firms into the global value chains (GVC) of various multinational corporations (MNC), though there have also been a few cases of FDI in the plastic industry. Table 2 identifies three distinct periods in the evolution of this industry, each representing a different GVC governance mode and a different set of regional features. The three modes identified are useful for analytical purposes, but they should not be considered as discrete phases in the life of this industry. This is because at any given moment there were different types of engagement depending on the MNC, the industry in which it operates (e.g. electronics or automobile), the way it 
chose to engage with local suppliers and the characteristics of the suppliers themselves.

According to data drawn primarily from secondary sources (Beira et al 2003, Beira and Gomes 2007, Gomes 2005), the GVC governance mode at the first stage was predominantly captive. Links with external markets were fairly informal and based on individual connections, particularly when they were mediated by intermediaries (mostly foreign). These intermediaries, with connections to clients in the USA and to a lesser extent in Europe, were crucial in helping to build capacity within SMEs. They would disseminate new technologies and encourage firms to meet the standards of their potential clients. Also they sustained informal networks both within the industry, by working with a variety of firms, and with external agents. The competitiveness of Portuguese firms was primarily a result of endogenous factors, namely the combination of low factors costs and the adoption of modern techniques of labour division and assembly-line production, which was a result of its origins in the glass industry (Beira et al 2003). This stood in contrast to mould makers in more advanced countries, which still relied on a traditional division of labour, where one worker would exercise control over the whole productive process (Beira et al. 2003).

Growth within the industry was supported overwhelmingly by spin-offs. Studying the period until 1970, Beira et al. (2003) identified 16 firms that descended directly from the two first major firms (each located in one of the main regions in figure 1), and only three companies that did not have a direct relationship with them. This entrepreneurialism based on spin-offs meant that new firms had relative high levels of absorptive capacity, and it ensured that the assembly line production techniques, and the orientation towards external markets, remained predominant. Finally it created a 
sense of community among entrepreneurs, which led to the emergence of informal networks within the industry that sustained knowledge spillovers (Beira and Gomes 2007). It also led to the creation of CEFAMOL in 1969, the association representing mould producers.

(Table 2 about here)

The second time period is characterized by three emerging features: the first was the diversification of the client base, which now included industries such as electronics, and was more geographically diverse, especially after Portugal joined the EU in 1986. According to Beira et al. (2003), by 1984 the toy industry accounted for less than $30 \%$ of total output, whereas electronics, home appliances and home products absorbed around $40 \%$. The second element was the introduction of CAD/CAM (Computer Aided Design/Computer Aided Machining) software, which led to the mechanisation of the production process and a reduced reliance on manual and tacit skills. According to Beira and Menezes (2003), Portuguese firms were worldwide pioneers in the introduction of this technology to the moulds industry. The third element was the emergence of locally owned and professionalised commercial firms, in comparison with the previous intermediaries, which often had more informal relations with local producers.

In this period the relational or modular governance modes became predominant. They were characterised by a higher degree of formality in relationships between local producers and TNCs, as production became more sophisticated and technologically advanced. This was probably the period when interactive learning, as defined by Lundvall (2010), was more prevalent. Suppliers would traditionally develop stable relations with a client or a commercialisation firm (though the latter were not as 
important as they are now, according to the interviewee from firm MP18 - table 1). This stability was crucial not only in guaranteeing high levels of demand, but also in facilitating technological transfer. It benefited both local firms and TNCs, since the former had access to knowledge and technology, while the latter could take advantage of lower prices (Beira and Gomes 2007, Mota and Castro 2004a).

At the local level, the mechanisms for knowledge transfer and learning became more formalised. In 1985 a centre for vocational training (CENFIM) was created in Marinha Grande, supplying semi-skilled individuals to this industry. Despite being publicly owned it was actively supported by local firms, who supplied their own workers and equipment to facilitate its establishment. In 1991 a technological centre was created in the same town. Technological centres are entities funded partially by the Portuguese national government, responsible for providing consultancy services to local firms, and increasingly engaged in international research projects for technological development. At the same time, the sector continued to grow on the basis on entrepreneurialism and spin-offs.

The final time period is marked by a shift towards market base forms of GVC governance, as a direct result of the increasing predominance of the automobile industry as the main client. This period is characterised by several trends: first is the increasing competition among firms, which pushes them to diversify their offer of goods and services (for example producing final plastic parts or offering consultancy services to clients) and to specialise in high complexity moulds. Specialisation is of course not a completely new trend in the life of this industry. For example one of the two regions (Oliveira de Azemeis) was known for having specialised in high-volume moulds several decades before. But at this stage it became increasingly difficult to be 
'simply' a mould producer, which is a shift compared to previous years, as explained by an interviewee:

With [the market] pressures many firms closed and there is clearly a distinction between those who closed and those who subsist. Before, many firms would only do moulds and many managers would stay in their firm waiting for orders. Today they have to go after the client, they have to participate in product development, in the industrial design, they have to make prototypes, produce the mould and provide after-sales support. (...) These firms are the biggest and even though there are still many small firms focused on production they will not survive. (...) We have a rule that all firms with an annual turnover below two million Euros are only on production and either they change or they will eventually perish.

(Client Manager at local branch in firm Bank 1; Author’s Interview)

The twin strategies of diversification in the scope of activities and specialisation in high-quality moulds are a result of the emergence of a market based form of GVC governance. Firms witnessed since the late 1990s that there was a lower degree of interdependence between clients and suppliers, a change also made possible by the increasing use of CAD/CAM and the introduction of quality certifications, such as the ISO 9001:2000. The latter diminish transaction costs in choosing suppliers and further reinforce the use of market based mechanisms. A lower degree of interdependence can be a positive development, since Portuguese mould makers have more flexibility to work with a wider range of clients. However, it also relieves the client of obligations towards the supplier, in terms of technology transfer and capacity building, usually at 
the expense of the latter. The result is a more competitive environment, because skills become less specific and unique. This is exemplified by the following quote:

The interaction with our clients was in the past much more important in our technological development, because our relation with our clients nowadays, most of them operating for the automobile industry, is essentially a commercial relation, where the economic interests are above technical and technological interests.

(Partner \& Manager of firm MP13; Author’s interview)

There are still opportunities for collective learning, particularly through the local networks that link owners and workers. The industry can also rely on its locational advantages, based on knowledge, skills, price and quick delivery times according to a report by USICT (2002). Nonetheless the stable external links with clients have been slowly eroding. A solution found by a small number of local firms has been to engage with international $R \& D$ networks, in collaborative research projects partly funded by the EU or other public resources. Engagement in these networks is however limited to a small number of firms with the necessary absorptive capacity and resources (financial, human or organisational) (AUTHOR'S PUBLICATION - CITATION TO BE ADDED LATER). This has led to a widening gap between those firms at the forefront of technological development and the others, who struggle to deal with the new competitive environment (see table 3 in the next section). This problem is exacerbated by the fact that even though there are strong informal networks, formal networks tend to remain closed due to a lack of trust.

In our firm we do not have the mentality of hiding things, because we believe that the moulds industry must get together and cooperate to be 
competitive worldwide. But that goes against old fashioned mentalities, because generally firms don't show anything to anyone.

(Partner and Manager at firm MP3; Author’s Interview)

The impact of these shifts has been the emergence of a starker hierarchy within the industry. A small number of firms have been capable of diversifying and/or specialising into niche markets to appropriate value within existing GVCs. But on the other hand, a significant amount of firms, who used to rely on interactive learning and strong supplier-client relationships, became ever more dependent on price-based competition and intermediaries (the impact of the latter will be discussed in greater detail further ahead in this paper). The impact of this change has been stagnant growth in the first decade of the $21^{\text {st }}$ century, and a reduction in the number of firms. In recent years the industry has again witnessed growth, which based on the trends identified at the time the case study was conducted is very likely the result of small number of core firms increasing their output.

Current trends suggest that overall the industry has been able to readjust and even benefit as a whole. This growth has also been the result of the industry diversifying towards the production of final goods (plastic parts), which explains the slight decline in the relative weight of exports (CEFAMOL 2015). Nonetheless, one should not discount the potential negative impact that the widening gap between firms might have on the industry. The Portuguese moulds industry has benefited until now from local knowledge externalities. The increasing concentration of activity in a small number of firms, and the creation of closed networks for knowledge creation and dissemination, might hinder these processes in the future. Also, the results from 2012 to 2014 could be influenced by contingent processes, such as high oil prices between 
2010 and 2014, especially if they are compared to the previous eight years that indicated a period of stagnation and even decline (figure 2).

\subsection{Heterogeneity at the local level}

As argued in the previous section, the nature of client supplier relationships is shifting, limiting the opportunities for interactive learning. This forces firms to search for strategies to engage with networks that allow them to access new knowledge. The problem with this strategy is that it has an unequal effect on firms. The predominance of SMEs, and the lack of resources to invest in long-term technological development, means that the number of those participating in these networks is relatively small. Table 4 uses data from the firms interviewed to create a typology based on their main activities, their relations with local and non local organisations (public and private) and their competitiveness. Since this is mostly qualitative data it is not possible to know whether these results can be extrapolated to the whole industry. However, after triangulating this information with statistical data and document analysis, it will be argued here that it is a fair assessment of this industry.

Firms in the top two tiers tend to use local/regional, national and international resources in a strategic way. Usually through the owner/manager of the firm, they are active members of CEFAMOL (Portuguese mould makers association) and engage with partners locally and internationally to develop technology. At the regional/national levels they often develop relationships with Universities, although it happens through personal connections and on an ad-hoc basis. Also they tend to make an effective use of policy instruments, mostly for innovation, export promotion and business development. Sometimes these instruments are managed through CENTIMFE, the technological centre supporting this industry, which is involved in several EU projects. On an international level there are several types of engagements. 
These include both the management and participation in the EU projects already mentioned, but also the involvement in international networks of mould makers. These channels facilitate the generation and diffusion of innovation.

Firms in row three, which according to interviewees are the most numerous in the industry, are those that struggle most with the market based governance mode. As the links with foreign clients erode and become more detached, these organisations struggle to deal with a new more competitive and volatile economic environment. They can still tap into strong informal local networks, that allow them to share knowledge and information, but it becomes more difficult to deal with demands, particularly from clients in the automobile industry. Increasingly they rely on commercialisation firms, which in some cases perform the same role that external clients did in the past in terms of technological diffusion. Finally firms in row four are usually dependent on bigger local firm that often outsource parts of the productive process. These small firms are important for the competitiveness of the moulds industry, but their connections are essentially local.

(Table 3 about here)

What is evident from this discussion is that a small number of firms has been able to position themselves in a variety of networks that allow them to remain technologically updated and competitive. This process however is not uniform. The danger in the future is that if only a small number of firms survive, this will affect negatively the local externalities that have made this industry competitive in previous decades. A 
potential solution might lie in the presence of commercialisation firms and intermediaries.

\subsection{Intermediaries as gatherers of global knowledge}

In this context, intermediaries are companies or individuals who collect orders from clients in the plastic industry and then distribute them to a network of local mould producers. In theory they offer several advantages to clients: they have the capacity to receive and coordinate large orders, because production is outsourced locally. Importantly, intermediaries can provide a set of value-added services that are necessary to increase competitiveness and that may not be available to all producers. A good commercialisation firm will offer engineering advice at the initial stage of the production process, a good system of production management that guarantees compliance with deadlines and quality, and an after-sales service.

It is difficult to know how many exist, because they do not have a statistical code. Nonetheless a database compiled by CEFAMOL in 2007 identified 29 commercialisation companies and 20 identified as project \& engineering firms, among a total of 445 firms. The second group, project \& engineering, are usually also intermediaries, although they see themselves primarily as firms providing technological services. The most crucial contribution of commercialisation firms in a context of market volatility is their dual role as gatherers of global knowledge on the evolution of international markets and the dissemination of technology among local firms. The first activity has two main components: one is client prospection in markets that have hitherto remained relatively unexplored. It demands an extensive knowledge and experience in a range of issues, such as the capacity to discuss 
technical requirements, and the management of softer issues such as legal constraints or cultural differences.

The second component is the gathering of knowledge about the capacities of moulds producers in different countries, and the evolution of client needs. As explained previously, at the same time that mould production moves eastwards, European producers retain an advantage in the production of highly complex, high-value added moulds. Nevertheless, MNCs use their market power and mobility to put downward pressure on prices. A commercialisation firm can use its knowledge of these trends to negotiate more favourable prices, since they will have prior knowledge of the type of moulds that plastic firms are reluctant to outsource in emerging economies.

They perform similar functions of multi-scalar coordination that bigger firms do by themselves, and have to a certain extent replaced them in coordinating knowledge diffusion. However they also act as gatekeepers and can therefore have a pernicious impact. This point was summarised by an interviewee who owned one of biggest engineering and commercialisation firms:

I believe the moulds industry in Marinha Grande has been kept alive due to the work of engineering firms and some commercialisation firms. Right now there are more intermediaries than mould producers, but $80 \%$ of them have no credibility, they are almost parasites who hurt the business, because they don't know how to do it. Something that they should buy for 40 and sell for 60 they are buying for 20 and selling for 30. That creates a certain amount of instability in the sector. Then there are 2 or 3 like us, and we are the support of many firms. 
Many of the producers interviewed for this case study often criticised these 'parasite' intermediaries for pushing down prices and often leading smaller firms to bankruptcy. The difficulty of accessing foreign clients has created an information asymmetry that has sometimes been filled by people with limited competencies, often referred to as an 'individual with a desk and a phone'. Their increasing presence within this industry could be said to result from this new stage of market based governance, which generates a new sense of insecurity among economic agents.

\section{Conclusions}

This paper used the case study of the moulds industry to explore how local dynamics supporting a successful industry evolve and adapt to the demands of foreign investments. It also discussed how the heterogeneity of local industries should be taken into consideration when evaluating the interaction between MNCs and local firms and the internal dynamics of territorial innovation systems. Finally, it addressed the role that intermediaries can play in a GVC, particularly in market based relationships between clients and suppliers. The discussion in previous pages points to three important conclusions.

First, the literature on territorial innovation should continue to expand the portfolio of research on the relational interaction between endogenous and exogenous regional characteristics. Despite several important previous contributions (Dawley 2007, Jakobsen et al 2005), not much is known yet about how different rounds of investment and divestment can affect regional assets or how different sectors and/or firms can affect local conditions differently (MacKinnon 2012). This paper sought to address this gap by adopting an evolutionary approach, demonstrating how local firms adapted to changing international circumstances. It also discussed how the automobile 
industry in particular affects the Portuguese moulds industry, due to its capacity to manage value chains on an international scale and thereby to exacerbate competition between places.

Second, a relational approach should avoid adopting a binary of region-MNC, because this fails to recognise the diversity and variety that exist within the same industry, even when firms are closely located. This is true even in a sector such as the Portuguese moulds industry, which at first sight would appear to be fairly homogeneous, since it refers to a fairly narrow industrial specialisation and it is composed of locally-owned SMEs. Nonetheless there are significant differences in terms of absorptive capacity and business strategy, which shapes how each firm engages with local, national or international networks in their search for knowledge and market opportunities. It also influences the generation of knowledge externalities at the local level, due to the persistence of what Staber $(2007,2009)$ called dysfunctional beliefs, that result in fragmented and closed networks. This is similar to what has been witnessed in other examples (Murphy 2012, Rabellotti and Schmitz 1999).

Finally the role of intermediaries in linking local firms with international markets would merit greater attention. This phenomenon is not new, and has been studied by a variety of authors (Howells 2006a, 2006b, Iturrioz et al 2015). Nonetheless, as the relationships between distant territories intensify and become more volatile (Dicken 2007), it is likely that those individuals or organisations that can coordinate the interaction between MNCs and local firms will become even more relevant. A better understanding of their contribution to this process, but also of the potential pitfalls of 
relying on them, would provide a window into a relatively hidden but important dimension of technological diffusion and regional development.

\section{References}

Amsden, A. H. (2001). The Rise of "The Rest": Challenges to the West from LateIndustrializing Economies. Oxford: Oxford University Press.

Beira E. (2007) Exportações de moldes industriais: Portugal (2006 e 2007) e a evolução dos preços (II), O Molde - Revista da CEFAMOL 74, 14-18.

Beira E., Gomes N. (2007) Indústria de moldes no Norte de Portugal. PROTAGONISTAS uma colecção de testemunhos, CENTIMFE, Marinha Grande.

Beira E., Crespo C., Gomes N. and Menezes J. (2003) Dos moldes à engenharia do produto, a trajectória de um cluster, Working papers "Mercados e Negócios" TSI WP34.

Beira E. and Menezes J. (2006) Tooling and engineering: the European perspective, Working papers "Mercados e Negócios" TSI WP62.

Beira E. and Menezes J. (2003) Inovação e indústria de moldes em Portugal. a introdução do CAD/CAM/CAE nos anos 80, Working papers "Mercados e Negócios" TSI WP30.

Blažek, J. (2015) Towards a typology of repositioning strategies of GVC/GPN suppliers: the case of functional upgrading and downgrading, Journal of Economic Geography, advanced online access at doi:10.1093/jeg/lbv044 
CEFAMOL (2015) Situação actual da indústria portuguesa de moldes, CEFAMOL, Marinha Grande.

Christopherson, S., \& Clark, J. (2007). Remaking regional economies: power, labor, and firm strategies in the knowledge economy. Abingdon: Routledge.

Cooke, P. (2012) Complex Adaptive Innovation Systems: relatedness and transversality in the evolving region. London: Routledge.

Cooke, P., Heidenreich, M., Braczyk, H.-J. (2004) Regional innovation systems: the role of governances in a globalized world. London: Routledge

Dawley S. (2007) Fluctuating Rounds of Inward Investment in Peripheral Regions: Semiconductors in the North East of England, Economic Geography 83 (1), 51-73.

Dicken P. (2007) Global shift: mapping the changing contours of the world economy. 5th ed, Sage, London.

Fallböhmer P., Altan T., Tönshoff H. and Nakagawa T. (1996) Survey of the die and mold manufacturing industry - practices in Germany, Japan, and the United States, Journal of Materials Processing Technology 59 (1-2), 158-168.

Fløysand, A., \& Jakobsen, S.-E. (2011). The complexity of innovation: A relational turn. Progress in Human Geography, 35(3), 328-344.

Gebreeyesus, M., Mohnen, P. (2013) Innovation Performance and Embeddedness in Networks: Evidence from the Ethiopian Footwear Cluster, World Development, 41, 302-316 
Gereffi G., Humphrey J. and Sturgeon T. (2005) The governance of global value chains, Review of International Political Economy 12 (1), 78-104.

Gomes N. (2005) A Indústria Portuguesa de Moldes para Plástico: História, Património e sua Musealização. Masters Thesis (Unpublished), University of Coimbra, Coimbra.

Howells J. (2006a) Intermediation and the role of intermediaries in innovation, Research Policy 35 (5), 715-728.

Howells, J. (2006b) Outsourcing for Innovation: Systems of Innovation and the Role of Knowledge Intermediaries. In: Miozzo, M. and Grimshaw, D. (eds.) Knowledge Intensive Business Services: Organizational Forms and National Institutions Cheltenham: Edward Elgar, p. 61-79

Iturrioz, C., Aragón, C., Narvaiza, L. (2015) How to foster shared innovation within SMEs' networks: Social capital and the role of intermediaries. European Management Journal 33(2), pp. 104-115.

Jakobsen, S.-E., Rusten, G., \& Fløysand, A. (2005). How green is the valley? Foreign direct investment in two Norwegian industrial towns. Canadian Geographer / Le Géographe Canadien, 49(3), 244-259.

Lee, H. H., \& Tan, H. B. (2006). Technology Transfer, FDI and Economic Growth in the ASEAN Region. Journal of the Asia Pacific Economy, 11(4), 394-410.

Li, X. (2011). Sources of External Technology, Absorptive Capacity, and Innovation Capability in Chinese State-Owned High-Tech Enterprises. World Development, 39(7), 1240-1248. 
Kleibert, J. M. (2016). Global Production Networks, Offshore Services and the Branch-Plant Syndrome. Regional Studies, 50(12), 1995-2009.

Lorentzen, A. (2007). The geography of knowledge sourcing - A case study of Polish manufacturing enterprises. European Planning Studies, 15(4), 467-486.

Lundvall, B.-Å. (2010). National systems of innovation: Toward a theory of innovation and interactive learning. London: Anthem Press.

MacKinnon D. (2012) Beyond strategic coupling: reassessing the firm-region nexus in global production networks, Journal of Economic Geography 12 (1), 227-245.

Marques, P. (2011). Theories and Policies of Innovation: A Critical Review. Geography Compass, 5 (11), 838-850.

Menkhoff, T. (1992) 'Xinyong or How to Trust Trust? Chinese Non-Contractual Business Relations and Social Structure: The Singapore Case', Internationales Asienforum, 23(1-2): 261-88.

Mota J. and Castro L. (2004a) Industrial agglomerations as localised networks: the case of the Portuguese mould industry, Environment and Planning A 36, 263-278.

Mota, J. and Castro, L. (2004b) A Capabilities Perspective on the Evolution of Firm Boundaries: A Comparative Case Example from the Portuguese Moulds Industry. Journal of Management Studies 41(2), pp. 295-316.

Moulaert, F., \& Sekia, F. (2003). Territorial innovation models: a critical survey. Regional Studies, 37(3), 289-302. 
Murphy, J. (2012) Global Production Networks, Relational Proximity, and the Sociospatial Dynamics of Market Internationalization in Bolivia's Wood Products Sector, Annals of the Association of American Geographers 102(1), pp. 208-233.

Myrdal, G. (1957). Economic Theory and Underdeveloped Regions. London:

Duckworth.

Neffke, F., Henning, M., Boschma, R., Lundquist, K.-J., \& Olander, L.-O. (2011). The Dynamics of Agglomeration Externalities along the Life Cycle of Industries. Regional Studies, 45(1), 49-65.

Pietrobelli, C., \& Rabellotti, R. (2011). Global Value Chains Meet Innovation Systems: Are There Learning Opportunities for Developing Countries? World Development, 39(7), 1261-1269.

Phelps, N. A., Mackinnon, D., Stone, I., \& Braidford, P. (2003). Embedding the multinationals? Institutions and the development of overseas manufacturing affiliates in Wales and North East England. Regional Studies, 37(1), 27-40.

Pike, A., Rodríguez-Pose, A, Tomaney, J (2006) Local and Regional Development. Oxon: Routledge.

Rabellotti, R., Schmitz, H. (1999) The Internal Heterogeneity of Industrial Districts in Italy, Brazil and Mexico, Regional Studies 33 (2), 97-108

Rodríguez-Pose, A., \& Fitjar, R. D. (2013). Buzz, Archipelago Economies and the Future of Intermediate and Peripheral Areas in a Spiky World. European Planning Studies, 21(3, SI), 355-372. 
Sasidharan, S., \& Kathuria, V. (2011). Foreign Direct Investment and R\&D:

Substitutes or Complements-A Case of Indian Manufacturing after 1991 Reforms.

World Development, 39(7), 1226-1239.

Staber, U. (2009) Collective learning in clusters: Mechanisms and biases,

Entrepreneurship \& Regional Development: An International Journal 21 (5-6), 553573

Staber, U. (2007) A Matter of Distrust: Explaining the Persistence of Dysfunctional Beliefs in Regional Clusters, Growth and Change 38 (3), 341-363

Tokatli, N. (2007). Asymmetrical Power Relations and Upgrading Among Suppliers of Global Clothing Brands: Hugo Boss in Turkey. Journal of Economic Geography, 7, $67-92$.

USICT (2002) Tools, dies and industrial moulds: competitive conditions in the United States and selected foreign markets. USICT - United States International Trade Commission, Washington.

Vale, M., \& Caldeira, J. (2007). Proximity and knowledge governance in localized production systems: The footwear industry in the north region of Portugal. European Planning Studies, 15(4), 531-548.

Vale, M., \& Carvalho, L. (2012). Knowledge Networks and Processes of Anchoring in Portuguese Biotechnology. Regional Studies, 47(7), 1018-1033.

Vedel, M. and Ellegaard, C. 2013. Supply risk management functions of sourcing intermediaries: an investigation of the clothing industry. Supply Chain Management: An International Journal 18(5), pp. 509-522. 
Winther, L. (2003) Local production systems and organization change: hierarchization and competing firm networks in Marinha Grande, Portugal. European Planning Studies 11(2), pp. 171-191. 
Table 1 - List of interviewees for the case study of the Portuguese moulds industry

\begin{tabular}{|c|c|c|c|c|c|}
\hline & & & & \multicolumn{2}{|c|}{ Mould producers only } \\
\hline $\begin{array}{c}\text { Name of } \\
\text { organisation }\end{array}$ & $\begin{array}{c}\text { Type of } \\
\text { organisation }\end{array}$ & $\begin{array}{c}\text { Position of person } \\
\text { interviewed }\end{array}$ & Location & $\begin{array}{l}\text { Number of } \\
\text { employees }\end{array}$ & $\begin{array}{l}\text { Year when it } \\
\text { was created }\end{array}$ \\
\hline CEFAMOL & Association of mould & Administrator & Marinha Grande & & \\
\hline CEFAMOL & producers & External Relations manager & Marinha Grande & & \\
\hline Bank 1 & Financial institution & $\begin{array}{l}\text { Client Manager in Leiria } \\
\text { branch }\end{array}$ & Leiria & & \\
\hline Bank 2 & Financial institution & $\begin{array}{l}\text { Client Manager in Leiria } \\
\text { branch }\end{array}$ & Leiria & & \\
\hline CNELPT* & $\begin{array}{l}\text { Central Government } \\
\text { Agency }\end{array}$ & Advisor & Lisbon & & \\
\hline QREN** & $\begin{array}{l}\text { Central Government } \\
\text { Agency }\end{array}$ & National coordinator & Lisbon & & \\
\hline MP1 & Mould producers & Administrator & $\begin{array}{l}\text { Oliveira de } \\
\text { Azeméis }\end{array}$ & 84 & 1965 \\
\hline MP2 & Mould producers & Administrator & Marinha Grande & 3 & Not available \\
\hline MP3 & Mould producers & Administrator & Marinha Grande & 80 & 1984 \\
\hline MP4 & Mould producers & Administrator & Marinha Grande & 28 & 1996 \\
\hline MP5 & Mould producers & Administrator & Marinha Grande & 40 & 1985 \\
\hline MP6 & Mould producers & Administrator & Marinha Grande & 50 & 1988 \\
\hline MP7 & Mould producers & Administrator & $\begin{array}{l}\text { Oliveira de } \\
\text { Azeméis }\end{array}$ & 150 & 1955 \\
\hline MP8 & Mould producers & Production manager & Porto de Mós & 20 & 1990 \\
\hline MP9 & Mould producers & Administrator & Leiria & 14 & Not available \\
\hline MP10 & Mould producers & Administrator & Marinha Grande & 42 & 1987 \\
\hline MP11 & Mould producers & Director for Exports & Marinha Grande & 40 & 1984 \\
\hline MP12 & Mould producers & Production manager & Marinha Grande & 45 & 1985 \\
\hline
\end{tabular}




\begin{tabular}{|c|c|c|c|c|c|}
\hline \multicolumn{3}{|c|}{ Continuation from previous page } & \multirow[b]{2}{*}{ Location } & \multicolumn{2}{|c|}{ Mould producers only } \\
\hline $\begin{array}{c}\text { Name of } \\
\text { organisation }\end{array}$ & $\begin{array}{c}\text { Type of } \\
\text { organisation }\end{array}$ & $\begin{array}{c}\text { Position of person } \\
\text { interviewed }\end{array}$ & & $\begin{array}{l}\text { Number of } \\
\text { employees }\end{array}$ & $\begin{array}{l}\text { Year when it } \\
\text { was created }\end{array}$ \\
\hline MP13 & $\begin{array}{l}\text { Mould producers \& } \\
\text { other services }\end{array}$ & Administrator & Marinha Grande & 250 & 1986 \\
\hline MP14 & Mould producers & Production manager & Aveiro & 22 & 1991 \\
\hline MP15 & Mould producers & Administrator & Marinha Grande & 20 & 1999 \\
\hline MP16 & Mould producers & Administrator & Marinha Grande & 7 & Not available \\
\hline MP17 & Mould producers & Administrator & Marinha Grande & 30 & 1984 \\
\hline MP18 & $\begin{array}{l}\text { Project and } \\
\text { Engineering/ } \\
\text { Commercialisation }\end{array}$ & Administrator & Marinha Grande & 36 & 1968 \\
\hline Plastic1 & Plastic producers & Managing director & Santo Tirso & & \\
\hline $\begin{array}{l}\text { CCDR - } \\
\text { Centro }\end{array}$ & $\begin{array}{l}\text { Regional } \\
\text { Development } \\
\text { Agency }\end{array}$ & Adjunct coordinator & Coimbra & & \\
\hline Steel & Steel suppliers & Engineer & Marinha Grande & & \\
\hline CENTIMFE & Technological centre & Financial administrator & Marinha Grande & & \\
\hline $\begin{array}{l}\text { Catholic } \\
\text { University } \\
\text { Porto }\end{array}$ & University & Academic & Oporto & & \\
\hline ISEG & University & Academic & Lisbon & & \\
\hline
\end{tabular}

* National coordinator for the Lisbon Strategy and the Technological Plan

** National Strategic Reference Framework 
Table 2 - Different stages of evolution in the Portuguese moulds industry

\begin{tabular}{|c|c|c|c|}
\hline Time period & Important features of the Portuguese moulds industry & Predominant GVC governance mode & Local dynamics \\
\hline $1940 s-1980 s$ & $\begin{array}{l}\text { Individual intermediaries linked external markets with } \\
\text { Portuguese firms } \\
\text { Growth in number of firms through spin-offs and } \\
\text { entrepreneurialism } \\
\text { Competitiveness based on path dependency (glass industry), } \\
\text { cost }\end{array}$ & $\begin{array}{l}\text { Captive governance mode predominant } \\
\text { Intermediaries and foreign clients participate in } \\
\text { capacity development of SMEs }\end{array}$ & $\begin{array}{l}\text { Spin-off firms spread absorptive capacity } \\
\text { and assembly line techniques } \\
\text { Emergence of local networks and } \\
\text { collective learning }\end{array}$ \\
\hline $1980 s-2000$ & $\begin{array}{l}\text { Diversification of client base to electronics and domestic } \\
\text { appliances } \\
\text { Introduction of CAD/CAM } \\
\text { Emergence of local intermediary firms } \\
\text { Competitiveness based on technological development, rapid } \\
\text { delivery of moulds, price, quality, specialisation in high } \\
\text { precision and high complexity moulds (USICT 2002) }\end{array}$ & $\begin{array}{l}\text { Relational and modular governance modes } \\
\text { predominate } \\
\text { Interactive learning between clients and suppliers }\end{array}$ & $\begin{array}{l}\text { Collective learning } \\
\text { Formalisation of training mechanisms - } \\
\text { increase in absorptive capacity } \\
\text { Entrepreneurialism and spin-off activity }\end{array}$ \\
\hline 2000 until present & $\begin{array}{l}\text { Increasing importance of automobile industry } \\
\text { Growing importance of intermediary firms, which now offer a } \\
\text { wider variety of services } \\
\text { Competitiveness based on same features as before, plus the } \\
\text { capacity to deliver a wider range of goods and services, } \\
\text { including engineering \& design, after-sales support and others }\end{array}$ & $\begin{array}{l}\text { Modular and market based governance } \\
\text { predominates } \\
\text { Increasingly moulds firms are entirely responsible } \\
\text { for technological development }\end{array}$ & $\begin{array}{l}\text { Advanced absorptive capacity - } \\
\text { increasing integration of highly-skilled } \\
\text { human capital } \\
\text { Adoption of quality standards; } \\
\text { codification of knowledge } \\
\text { R\&D networks and policy } \\
\text { Persistence of 'dysfunctional beliefs' }\end{array}$ \\
\hline
\end{tabular}


Source: author's research 
Table 3 - Classification of moulds firms according to their size, diversity, competitiveness, and interactions with GPNs

\begin{tabular}{|c|c|c|c|}
\hline Size & Activities & $\begin{array}{l}\text { Relations with local and non local } \\
\text { actors }\end{array}$ & Competitiveness \\
\hline $\begin{array}{l}\text { Between } 50 \text { and } 150 \\
\text { employees, although they } \\
\text { might be smaller. Also a small } \\
\text { group within the industry, but } \\
\text { larger than the previous one. }\end{array}$ & $\begin{array}{l}\text { Tend to be highly specialised (e.g. } \\
\text { small complex moulds or large scale } \\
\text { moulds). Usually have a small } \\
\text { commercialisation department, } \\
\text { project and engineering capacity and } \\
\text { provide after-sales support. }\end{array}$ & $\begin{array}{l}\text { Relatively strong presence in the industry. } \\
\text { Establish strong local and non local } \\
\text { relationships but more focused on specific } \\
\text { goals. }\end{array}$ & $\begin{array}{l}\text { High. Offer high value added } \\
\text { goods and services. Have } \\
\text { capacity to integrate } \\
\text { advanced technology and } \\
\text { perform R\&D }\end{array}$ \\
\hline
\end{tabular}


Table 3 (continued from previous page)

\begin{tabular}{|c|c|c|c|}
\hline Size & Activities & $\begin{array}{l}\text { Relations with local and non local } \\
\text { actors }\end{array}$ & Competitiveness \\
\hline $\begin{array}{l}\text { Up to } 150 \text { employees. Large } \\
\text { part of the whole industry. }\end{array}$ & $\begin{array}{l}\text { Tend to be more reactive to client } \\
\text { demands. Bigger firms have both } \\
\text { commercial and project and } \\
\text { engineering departments but smaller } \\
\text { ones do not. }\end{array}$ & $\begin{array}{l}\text { Well connected informally to other local } \\
\text { agents. Smaller firms are increasingly } \\
\text { dependent on intermediaries. Might be } \\
\text { part of CEFAMOL and CENTIME but } \\
\text { their engagement is sporadic and reactive. }\end{array}$ & $\begin{array}{l}\text { Medium. Highly skilled } \\
\text { employees and advanced } \\
\text { technology. Tend to have low } \\
\text { skilled managers and high } \\
\text { levels of inefficiency. } \\
\text { Technological development } \\
\text { is reactive and based on } \\
\text { client demands. }\end{array}$ \\
\hline
\end{tabular}

Source: author's research 
Figure 1 - Two main locations of the Portuguese moulds industry for plastic injection

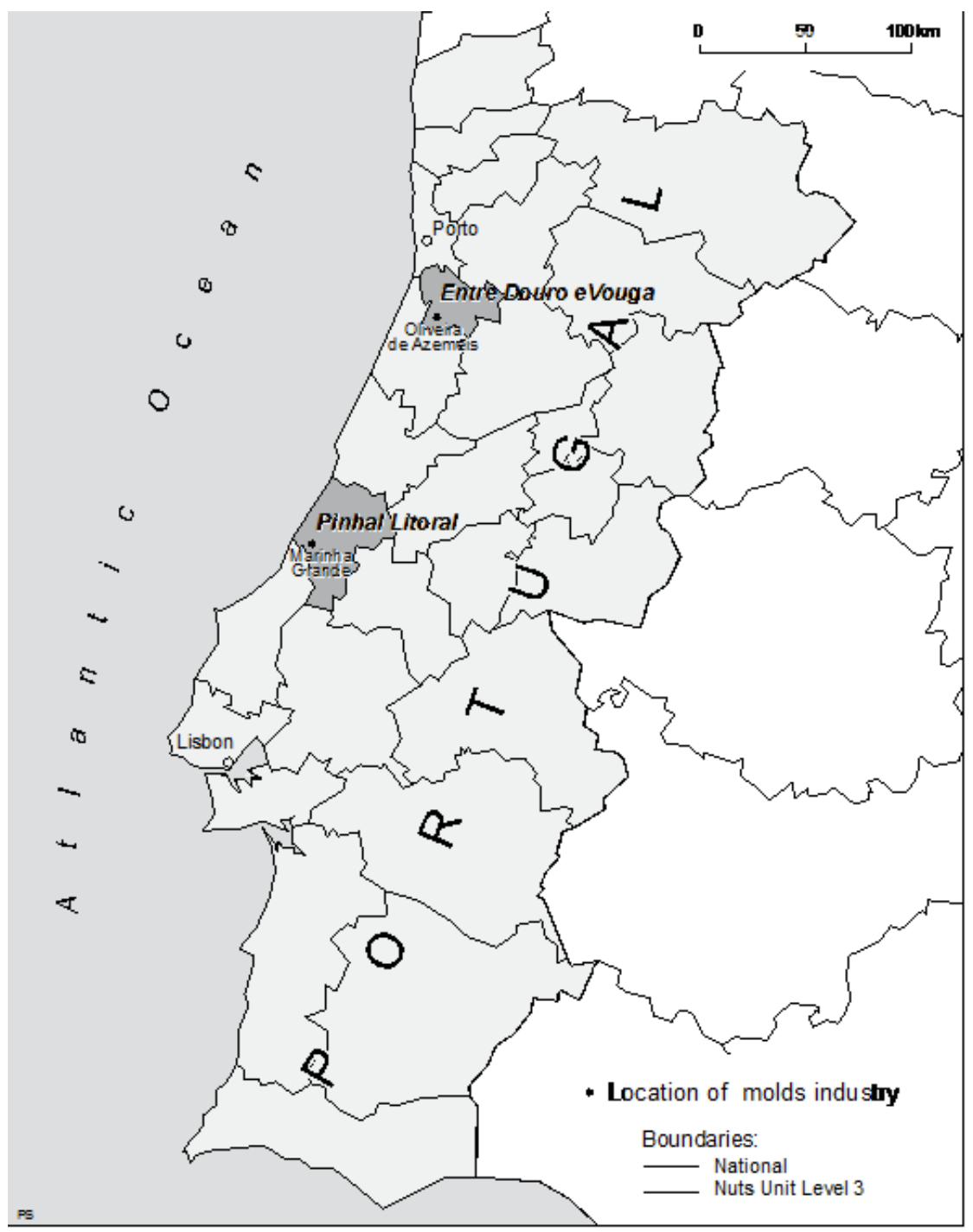

Source: author's research 
Figure 2 - Production and exports from the Portuguese moulds industry (in million Euros)

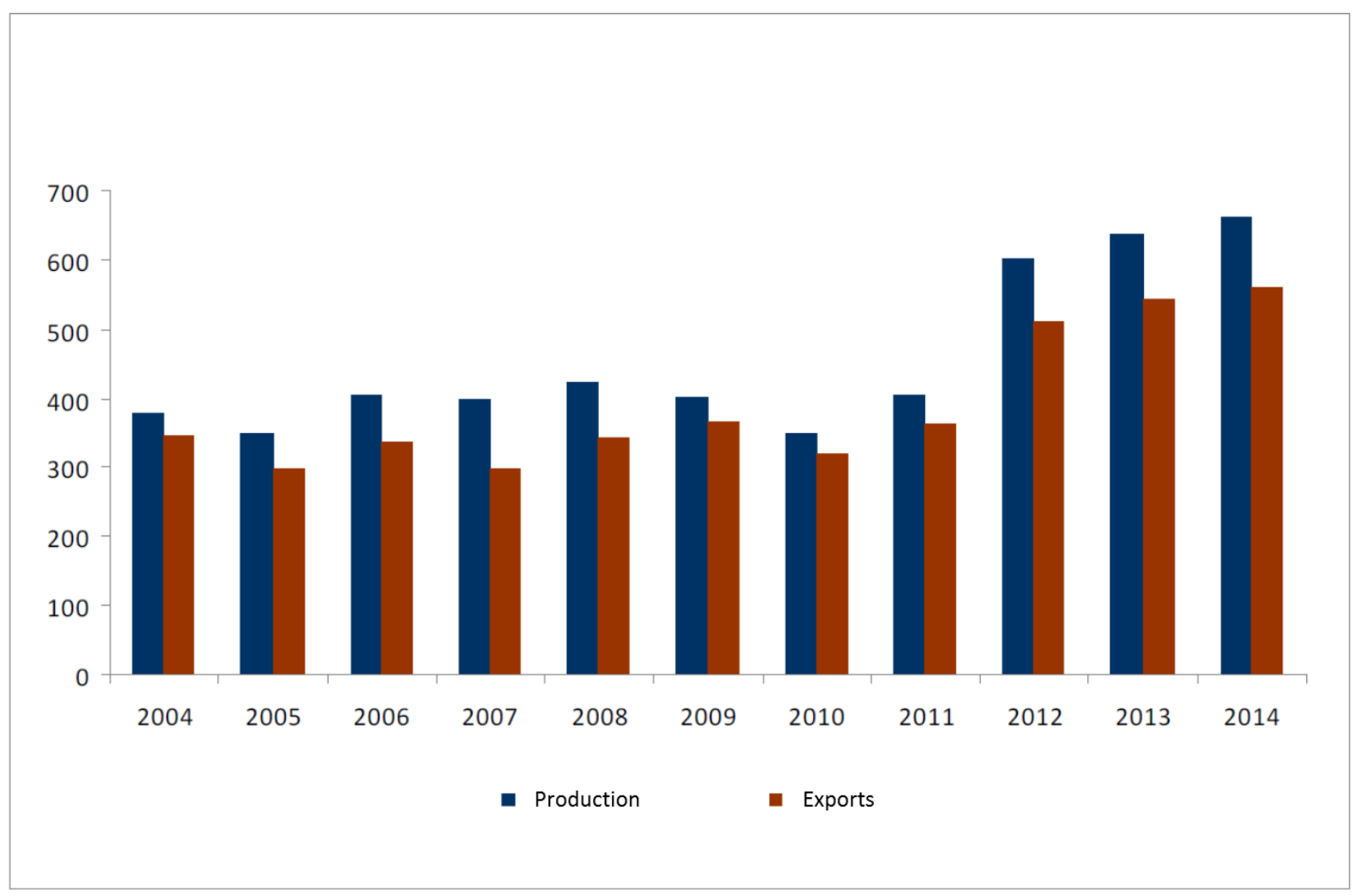

Source: CEFAMOL (2015) 


\section{List of tables and figures}

Table 1 - List of interviewees for the case study of the Portuguese moulds industry

Table 2 - Different stages of evolution in the Portuguese moulds industry

Table 3 - Classification of moulds firms according to their size, diversity, competitiveness, and interactions with GPNs

Figure 1 - Two main locations of the Portuguese moulds industry for plastic injection

Figure 2 - Production and exports from the Portuguese moulds industry (in million Euros) 